\title{
Sintesis Nanopartikel Perak Menggunakan Bioreduktor Ekstrak Daun Teh Hijau (Camellia Sinensis) dengan Iradiasi Microwave
}

\section{Synthesis of Silver Nanoparticles by Using Bioreductor of Green Tea Leaf Extract (Camellia Sinensis) by Microwave Irradiation}

\author{
${ }^{1)}$ Dewi Mustika Rahim, ${ }^{2)}$ Netti Herawati, ${ }^{3)}$ Hasri \\ ${ }^{123)}$ Jurusan Kimia Fakultas Matematika dan Ilmu Pengetahuan Alam \\ Universitas Negeri Makassar, Jl. Dg Tata Raya Makassar, Makassar 90224 \\ Email: dewimustika13@gmail.com
}

\begin{abstract}
ABSTRAK
Telah dilakukan penelitian tentang sintesis nanopartikel perak menggunakan bioreduktor ekstrak daun teh hijau (Camellia Sinensis) dengan iradiasi microwave. yang untuk mengetahui pengaruh waktu sintesis dan pengaruh $\mathrm{pH}$ stabilizer terhadap sintesis nanopartikel perak ekstrak daun teh hijau dengan iradiasi microwave serta karakterisasinya. Larutan $\mathrm{AgNO}_{3} 3 \mathrm{mM}$ direduksi menggunakan ekstrak daun teh hijau dan di iradiasi microwave pada variasi waktu sintesis 1-5 menit. Penentuan waktu sintesis optimal menggunakan spektrofotometer UV-Vis diukur setiap 1 menit. Nanopartikel dengan waktu sistesis 4 menit, $\mathrm{pH}$ stabilizer menggunakan asam sitrat dan $\mathrm{NaOH}$ dengan $\mathrm{pH}$ 6-9. Karakterisasi nanopartikel menggunakan instrumen SEM-EDS (Scanning Electron Microscopy-Energy Dispersive X-Ray Spectroscopy) dan PSA (Particle Size Analyzer). Hasil penelitian menunjukkan bahwa waktu sintesis optimal adalah 4 menit. Morfologi nanopatikel perak yang dikarakterisasi menggunakan SEM (Scanning Electron Microscopy) yang dihasilkan cenderung beragregasi. Adanya kecenderungan nanopartikel untuk beragregasi menyebabkan ukuran atau diameter nanopartikel tidak seragam. Ukuran dan distribusi ukuran nanopartikel perak dikarakterisasi menggunakan PSA(Particle Size Analyzer) dihasilkan pada pH 6 antara 31,01 - 402,44 $\mathrm{nm}$ dengan rata-rata ukuran sebesar $91 \mathrm{~nm}, \mathrm{pH} 7$ antara 35,03 - 740,899 nm dengan rata-rata ukuran sebesar 106,3 nm, $\mathrm{pH} 8$ antara 39,58 - 193,48 nm dengan rata-rata ukuran 71,7, dan $\mathrm{pH} 9$ antara $35,03-171,25 \mathrm{~nm}$ dengan rata-rata ukuran sebesar 64,4 nm. Disimpulkan bahwa hasil sintesis nanopartikel perak terkecil diperoleh pada $\mathrm{pH} 9$ dan waktu sintesis 4 menit.
\end{abstract}

Kata kunci: Ekstrak Daun Teh Hijau, Nanopartikel Perak, Iradiasi Microwave

\begin{abstract}
Research has been carried out on the synthesis of silver nanoparticles using a bioreductor of green tea leaf extract (Camellia
\end{abstract}


Sinensis) by irradiation microwave. This research aimed to determine the effect of synthesis time and $\mathrm{pH}$ stabilizer on the synthesis of silver nanoparticles of green tea leaf extract by microwave irradiation and it's characterization. The $3 \mathrm{mM}$ AgNO3 solution was reduced using green tea leaf extract and microwave irradiated in a variation of the synthesis time 1-5 minutes. The determining optimum of sythesis time was done by analysis of UV-Vis spectrum for every minutes. Nanoparticles with a synthesis time of 4 minutes, the stabilizer of silver nanoparticles used citric acid and $\mathrm{NaOH}$ with a $\mathrm{pH}$ of 6-9. Characterization of nanoparticles using SEM-EDS instrument (Scanning Electron Microscopy-Energy Dispersive X-Ray Spectroscopy) and PSA (Particle Size Analyzer). The results showed that the optimal synthesis time was 4 minutes. The morphology of silver nanopaticles characterized using SEM produced tends to aggregate. The tendency of nanoparticles to aggregate causes size or diameter of nanoparticles was random. The size and distribution of size silver nanoparticles characterized using PSA were produced at $\mathrm{pH} 6$ between $31.01-402.44 \mathrm{~nm}$ with an average size of $91 \mathrm{~nm}, \mathrm{pH} 7$ between 35.03 - 740,899 nm with an average size amounting to $106.3 \mathrm{~nm}, \mathrm{pH} 8$ between $39.58-193.48 \mathrm{~nm}$ with an average size of 71.7, and $\mathrm{pH} 9$ between $35.03-171.25 \mathrm{~nm}$ with an average size of $64.4 \mathrm{~nm}$. It was concluded that the synthesis of the smallest silver nanoparticles was obtained at $\mathrm{pH} 9$ and synthesis time of 4 minutes.

Keywords: Green Tea Leaf Extract, Silver Nanoparticles, Microwave

Irradiation

\section{PENDAHULUAN}

Salah satu bidang material yang banyak mendapat perhatian dalam beberapa tahun terakhir adalah nanopartikel karena memiliki peran penting dalam kemajuan teknologi. Nanopartikel dapat berupa logam, oksida logam, semikonduktor, polimer, dan senyawa organik. Nanopartikel perak adalah salah satu nanopartikel yang paling banyak diteliti dan aplikasinya yang paling umum adalah penggunaan nanopartikel perak sebagai antibakteri, substansi antimikroba, anti inflamasi, anti agiogenesis, anti jamur, antiviral, dan anti aktivitas platelat (Mallikarjuna, dkk., 2011).
Nanopartikel perak dapat disintesis dengan metode fisika, kimia dan biologi. Meskipun metode fisika dan kimia menghasilkan partikel yang murni, namun metode tersebut mahal dan tidak ramah lingkungan. Sehingga terdapat metode baru, yaitu biosintesis nanopartikel berbasis tumbuhan sebagai bioreduktor. Penggunaan senyawa organik tumbuhan untuk sintesis nanopartikel merupakan metode yang ramah lingkungan, serta lebih sederhana. Disamping itu, jenis tumbuhan yang mengandung bahan reduktor ini cukup melimpah dan mudah didapatkan di wilayah Indonesia.

Beberapa penelitian telah mensintesis nanopartikel perak 
menggunakan ekstrak tumbuhan, seperti penggunaan ekstrak daun bambu sebagai pereduksi ion perak dari senyawa $\mathrm{AgNO}_{3}$ menjadi nanopartikel perak pada suhu $65^{\circ} \mathrm{C}$ diperoleh kurang dari $100 \mathrm{~nm}$ (Yasin, 2013). Sintesis nanopartikel perak menggunakan ekstrak daun tapak dara, dengan ukuran nanopartikel rata-rata 35-55 nm berbentuk acak kubik (Ponarulselvam, dkk., 2012). Sintesis nanopartikel perak menggunakan ekstrak daun ranti dan kembang telang diperoleh nanopartikel dengan ukuran rata-rata $20 \mathrm{~nm}$ (Krithiga, dkk., 2015). Sintesis nanopartikel perak menggunakan ekstrak daun stroberi, diperoleh nanopartikel perak berbentuk bola dengan ukuran 9-15 nm (Naik,dkk.,2013). Sintesis nanopartikel perak menngunakan ekstrak metanol daun teh hijau, diproleh ukuran 157,8 nm (Negara, 2017).

Daun teh mengandung senyawa katekin turunan dari senyawa flavonoid yang memiliki gugus hidroksil $(-\mathrm{OH})$ dapat berperan dalam proses reduksi ion $\mathrm{Ag}^{+}$menjadi $\mathrm{Ag}$ nanopartikel (Loo, dkk., 2012). Sifat dari senyawa katekin yang mudah mengalami oksidasi yaitu pelepasan atau pendonor elektron untuk menghambat molekul antioksidan menjadi radikal bebas. Berdasarkan sifat antioksidannya ini dan mudahnya mengalami oksidasi dapat mempermudah proses pembentukan nanopartikel perak yang mengalami proses reduksi.

Pada umumnya sintesis nanopartikel perak dilakukan dengan metode pemanasan konvensional, namun metode tersebut membutuhkan waktu yang lama, pemanasan tidak merata dan tidak efisien. Oleh karena itu, muncul metode menggunakan iradiasi microwave. Iradiasi microwave dapat mempercepat waktu reaksi dan meningkatkan hasil tanpa menyebabkan perubahan berarti dalam reaksi kimia, serta memiliki keuntungan yaitu pemanasan homogen yang dapat berpengaruh secara langsung pada proses nukleasi sintesis nanopartikel perak (Punuri, dkk., 2012). Beberapa penelitian menggunakan metode tersebut yaitu, sintesis nanopartikel menggunakan bioreduktor daun jambu dengan iradiasi microwave diperoleh ukuran nanopartikel 21,04 nm (Arifin, dkk., 2016). Sintesis nanopartikel nanopartikel dengan menggunakan daun Stigmaphyllon littorale dengan Iradiasi microwave diperoleh ukuran 23 nm (Kudle, dkk., 2013). Sitntesis nanopartikel dengan ekstrak daun sirih diperoleh ukuran rata-rata $11,94 \mathrm{~nm}$ (Purnamasari, dkk., 2016).

Sejauh ini penelusuran peneliti, penggunaan Iradiasi microwave terhadap sintesis nanopartikel perak menggunakan ekstrak daun teh hijau belum dilakukan. Sehingga penelitian ini, bertujuan mensintesis nanopartikel perak menggunakan ekstrak daun teh hijau dengan bantuan Iradiasi microwave.

\section{METODE PENELITIAN}

\section{A. Alat dan Bahan}

Alat yang digunakan pada penelitian ini adalah wadah maserasi, alat-alat gelas, neraca analitik, microwaveElectroluxEMM2021MW,c 
entrifuge,stopwatch,blender,Spektrofo -tometer UV-Vis Shimadzu tipe UV 2450, SU3500 Scanning Electron Microscopy (SEM), dan Particle Size Analyzer (PSA) merk HORIBA SZ100.

Bahan-bahan yang digunakan dalam penelitian ini adalah serbuk halus daun teh (Camellia Sinensis), akuabides, metanol p.a, $\mathrm{AgNO}_{3}$ padat, Asam sitrat padat, larutan $\mathrm{NaOH} 0,1$ $\mathrm{M}$, kertas saring Whatman, aluminium foil.

\section{B. Prosedur Kerja \\ 1. Persiapan Bahan}

Daun teh hijau (Camellia sinensis) yang telah dibersihkan kemudian dikeringkan pada suhu kamar. Daun yang telah kering dipotong kecil-kecil kemudian dihaluskan dengan menggunakan blender, setelah itu ditimbang sebanyak $100 \mathrm{~g}$.

\section{Ekstraksi}

Sebanyak 100 gram daun teh halus dimaserasi dengan $1000 \mathrm{~mL}$ metanol. Maserasi dilakukan sebanyak 2 kali 48 jam disertai pengocokan/pengadukan setiap 12 jam. Kemudian didekantasi dan disaring dengan corong Buchner yang dilapisi kertas saring Whatman. Ekstrak yang diperoleh kemudian dipekatkan dengan menggunakan evaporator hingga tersisa seperlima dari volume awal. Ekstrak kental yang diperoleh selanjutnya dapat langsung digunakan untuk proses sintesis nanopartikel perak. Ekstrak daun teh disimpan dalam lemari es ketika tidak digunakan.

\section{Sinstesis Nanopartikel Perak}

Ekstrak daun teh hijau menjadi 6 bagian (satu sebagai blanko, dan lima bagian perlakuan sebagai pengujian pembentukan nanopartikel). Sebanyak $5 \mathrm{~mL}$ ekstrak daun teh ditambahkan kedalam labu erlenmeyer $250 \mathrm{~mL}$, yang telah berisi larutan $\mathrm{AgNO}_{3} 3 \mathrm{mM}$ sebanyak $100 \mathrm{~mL}$. Larutan kemudian dipanaskan dengan microwave pada daya 380 Watt dengan variasi waktu 1-5 menit, selanjutnya dianalisis dengan spektrofotometer UV-Vis untuk melacak saat terbentuknya nanopartikel perak yang ditandai dengan munculnya puncak absorbansi pada panjang gelombang $385-515 \mathrm{~nm}$ (Yasin, dkk., 2013) dan atau terjadinya perubahan warna larutan, dari warna kuning menjadi coklat. Larutan sampel yang diperoleh disentrifugasi pada $8900 \mathrm{rpm}$ selama 45 menit, endapan yang dihasilkan lalu dicuci dengan akuabides lalu disentrifugasi kembali, proses ini dilakukan sebanyak 4-5 kali.Hasil sentrifugasi terkahir kemudian ditambahkan $10 \mathrm{~mL}$ Asam Sitrat $0,01 \mathrm{M}$ dan diatur $\mathrm{pH} 6,7,8$,dan 9 menggunakan $\mathrm{NaOH} \quad 0,1 \quad \mathrm{M}$. Selanjutnya disentrifugasi kembali pada 8900 rpm selama 40 menit, lalu endapan dicuci dengan akuabides dan disentrifugasi kembali selama 20 menit. Endapan yang diperoleh dikeringkan menggunakan oven.

\section{Karakterisasi Perak \\ Morfologi nanopartikel perak dianalisis dengan menggunakan instrumen Scanning Electron}


Microscopy (SEM). Nanopartikel juga dianalisis dengan instrument EnergyDispersive X-Ray Spectroscopy (EDS) untuk mengetahui komposisi kimianya. Endapan yang telah dikeringkan dengan oven, kemudian dianalisis dengan menggunakan SEMEDS dan Larutan yang diperoleh kemudian dianalisis dengan instrumen Particle Size Analyzer (PSA) untuk mengetahui distribusi ukuran nanopartikel perak.

\section{HASIL DAN PEMBAHASAN}

\section{A. Ekstraksi Daun Teh Hijau}

Daun teh hijau halus diekstrak menggunakan pelarut metanol selama 4 x 24 jam. Ekstrak daun teh yang berwarna hijau pekat seperti yang terlihat pada Gambar 1.

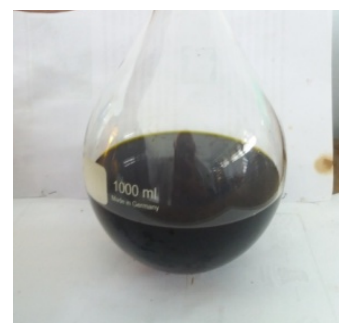

Gambar 1. Ekstrak Daun Teh Hijau

\section{B. Sintesis Nanopartikel Perak dengan Metode Iradiasi Microwave}

Terbentuknya nanopartikel perak secara umum dapat dilihat pada perubahan warna larutan, dimana larutan menjadi coklat kehitaman. Seiring bertambahnya waktu, maka warna dari larutan semakin pekat, diakibatkan senyawa fenolik yang terkandung dalam ekstrak daun teh hijau yang berupa katekin menjadi bioreduktor karena senyawa tersebut memiliki gugus -OH yang dapat mereduksi ion perak $\left(\mathrm{Ag}^{+}\right)$menjadi nanopartikel perak (Ag).

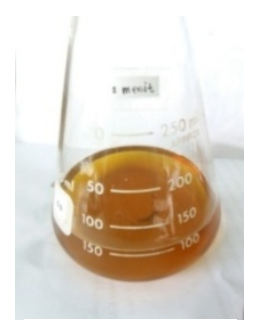

1 menit

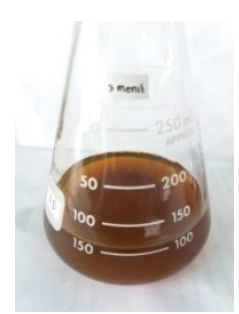

3 menit

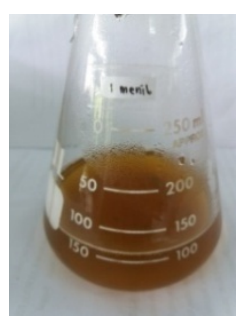

2 menit

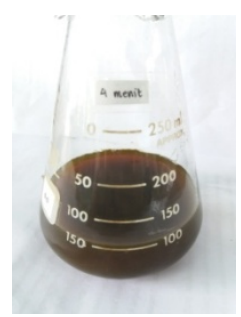

4 menit

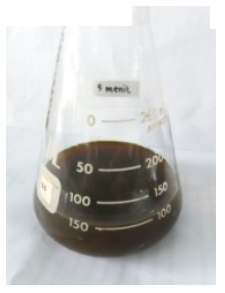

5 menit

Gambar 2. Perubahan Warna Larutan yang Terjadi Seiring Bertambahnya Waktu Sintesis

Pemanasan microwave lebih baik daripada pemanasan konvensional karena, secara konsisten diperoleh hasil nanopartikel dengan ukuran kecil, distibusi ukuran lebih ringkas, dan kristalisasi derajat tinggi. Sehingga pada penilitian ini, diperoleh ukuran nanopartikel perak yang lebih kecil. 
Selanjutnya, untuk membuktikan bahwa reaksi reduksi sedang berlangsung maka dilakukan pengukuran absorbansi panjang gelombang dengan menggunakan spektrofotometer UV-Vis. Indikasi terbentuknya nanopartikel diketahui dengan terbentuknya puncak absorbansi pada kisaran panjang gelombang $\quad 385-510 \quad \mathrm{~nm}$ (Nanocomposix.com, 2014). Nanopartikel yang telah disintesis kemudian dianalisis menggunakan UV-Vis dapat dilihat pada Gambar 3.

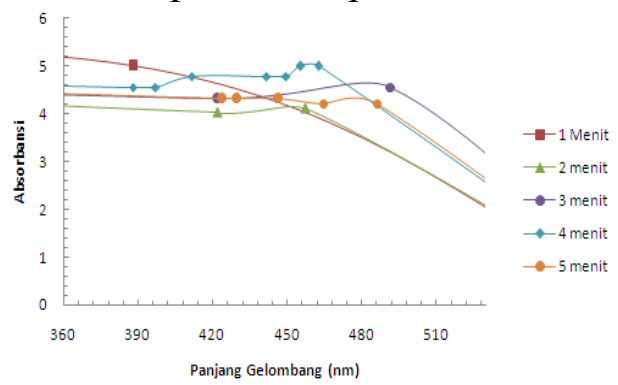

Gambar 3. Spektrum UV-Vis Sintesis Nanopartikel Perak pada Berbagai Rentang Waktu

Berdasarkan hasil pengukuran UV-Vis diperoleh waktu optimum sintesis nanopartikel perak adalah menit ke 4, karena memiliki absorbansi yang tinggi yang menandakan partikel lebih kecil (Purnamasari,2015) dan memiliki peak spectrum panjang gelombang pembentukan nanopartikel perak yang banyak.

\section{Penambahan Stabilizer pada Sintesis Nanopartikel Perak}

Endapan nanopartikel perak yang telah dicuci dengan akuabides, selanjutnya untuk mencegah terjadinya agregasi digunakan asam sitrat $0,01 \mathrm{M}$. Asam sitrat akan bertindak sebagai stabilizer (Mohapattra, dkk., 2015). Di mana gugus karboksilat pada asam sitrat berperan sebagai penstabilisasi dan gugus hidroksil menutupi nanopartikel, terjadi interaksi ikatan hidrogen antar molekul dipermukaan, yang meningkatkan stabilisasi koloid (Pacioni, dkk., 2015). Penambahan $\mathrm{NaOH}$ untuk mengontrol $\mathrm{pH}$ larutam (Mohaputra, dkk, 2015) . Pada penelitian ini digunakan $\mathrm{NaOH} 0,1 \mathrm{M}$ untuk mengatur $\mathrm{pH} 6,7,8$, dan 9. $\mathrm{pH}$ dapat mempengaruhi distribusi ukuran partikel. Kemampuan berbagai gugus fungsi untuk mereduksi berkurang dengan adanya konsentrasi $\mathrm{H}+$ yang tinggi pada kondisi $\mathrm{pH}$ rendah. Namun saat $\mathrm{pH}$ ditingkatkan kemampuan berbagai kemampuan gugus fungsi sebagai pereduksi meningkat sehingga meningkatkan kestabilan (Nurbayasari, dkk., 2017).

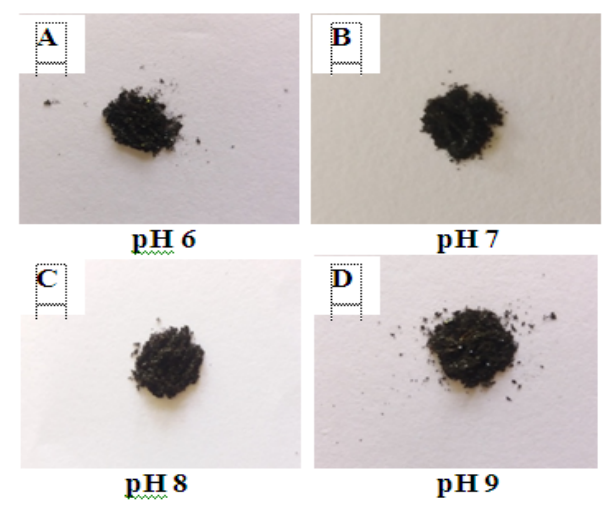

Gambar 4. Serbuk Hasil Sintesis Nanopartikel Perak 


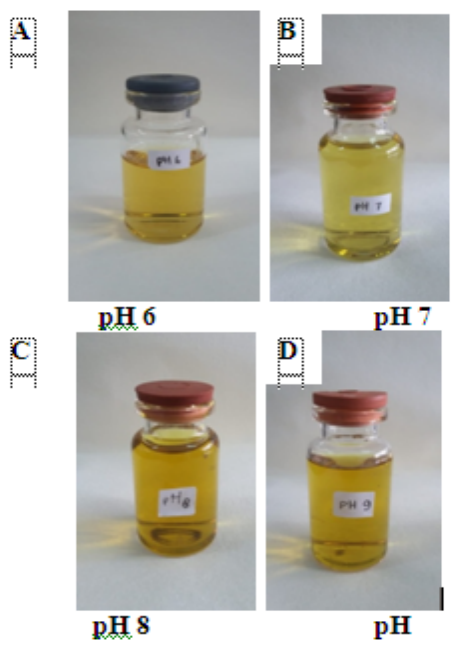

Gambar 5. Larutan Nanopartikel Perak

hasil $\begin{array}{cr}\text { Endapan yang diperoleh dari } \\ \text { sentrifugasi }\end{array}$ dikeringkan untuk memperoleh serbuk nanopartikel perak. Hasil sintesis nanopartikel perak, diperoleh serbuk nanopartikel pada pH 6 yaitu 0,02387 gram dengan rendemen sebesar 75,25\%. Untuk pH 7 diperoleh serbuk nanopartikel sebanyak 0,02571 gram dengan rendemen sebesar 81,07\%. Dan untuk $\mathrm{pH} 8$ dan $\mathrm{pH} 9$ masingmasing diperoleh serbuk nanopartikel sebanyak 0,02806 gram dan 0,0312 gram dengan rendemen sebesar $88,48 \%$ dan $98,39 \%$.

\section{Karakterisasi Nanopartikel} Perak

1. Scanning Elektron Microscope (SEM)

Analisis SEM bertujuan untuk menunjukkan morfologi partikel. Hasil pengamatan SEM pada gambar 6 memperlihatkan bahwa morfologi nanopartikel perak pada $\mathrm{pH}$ 6-9 yang dihasilkan hampir sama dan tidak terlalu terlihat perbedaan yang signifikan, namun menunjukkan adanya distribusi partikel yang tidak merata. cenderung beragregasi, dimana umumnya partikel-partikel di bawah pengamatan mikroskop cenderung menggumpal. Kecenderungan nanopartikel untuk beragregasi disebabkan oleh gaya van der Waals dalam larutan nanopartikel. Hal ini menunjukkan bahwa pengaruh $\mathrm{pH}$ stabilizer tidak berpengaruh pada morfologi nanopartikel perak yang dihasilkan. 

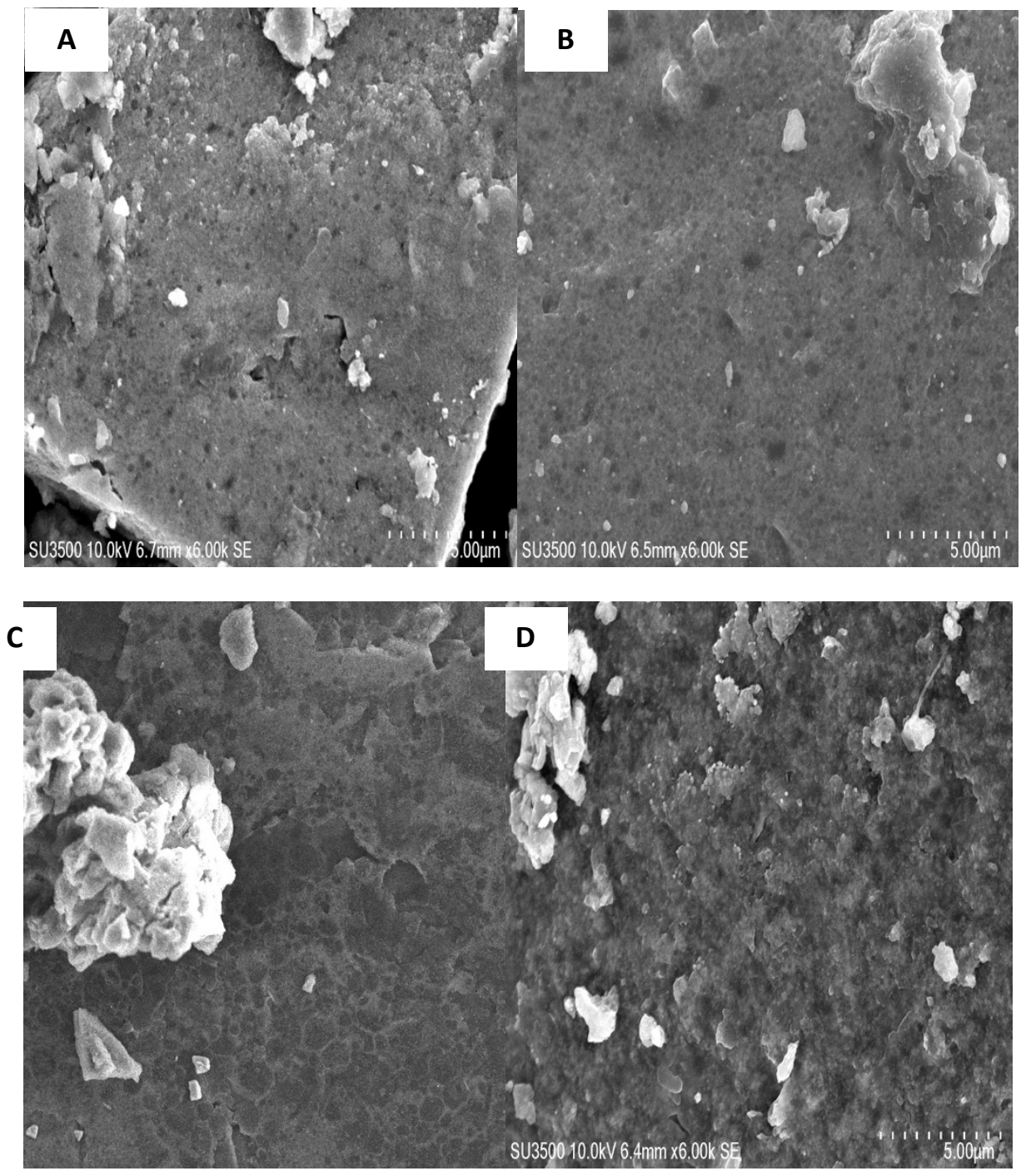

Gambar 6. Morfologi Nanopartikel Perak (A) $\mathrm{pH}$ 6, (B) $\mathrm{pH}$ 7, (C) $\mathrm{pH}$ 8, dan (D) $\mathrm{pH} 9$

Komposisi kimia nanopartikel perak hasil sintesis dapat diketahui melalui hasil analisis instrumen Energy-dispersive $X$-ray spectroscopy (EDS). Persentase komposisi kimia sampel diperoleh menggunakan alogaritma ZAF, dimana $\mathrm{Z}$ adalah nomor atom unsur, $A$ adalah absorbansi, dan F adalah nilai fluoresence (seallabs.com, 2015).
Melalui alogaritma tersebut diperoleh persen atom dan berat dari sampel. Persen komposisi kimia nanopartikel perak yang diperoleh dapat dilihat pada Gambar 7.

Berdasarkan data EDS yang ditunjukkan Tabel 4.2 nampak bahwa komposisi \% Massa Perak (Ag) terbesar pada nanopartikel perak hasil sintesis dengan $\mathrm{pH} 8$ yaitu sebesar 
40,9 \% dari berat sampel nanopartikel yaitu sebanyak 0,02806 g. Dilanjut dengan nanopartikel perak pada $\mathrm{pH} 9$ yaitu sebesar 38,41 \% dari berat sampel nanopartikel yaitu sebanyak 0,0312 g. Dan nanopartikel perak hasil sintesis $\mathrm{pH} 7$ dan $\mathrm{pH} 6$ yaitu sebesar $38.41 \%$ dan $29,96 \%$ dari berat sampel nanopartikel yaitu sebanyak $0,02571 \mathrm{~g}$ dan $0,02387 \mathrm{~g}$.

\begin{tabular}{|c|c|c|}
\hline $\mathrm{pH}$ & Unsur/ Elemen & Massa $(\%)$ \\
\hline \multirow{4}{*}{6} & Karbon (C) & 36,65 \\
\hline & Oksigen $(\mathrm{O})$ & 34,38 \\
\hline & Klor $(\mathrm{Cl})$ & 2,02 \\
\hline & Perak (Ag) & 29,96 \\
\hline \multirow{5}{*}{7} & Karbon ( C ) & 26,43 \\
\hline & Oksigen $(\mathrm{O})$ & 26,87 \\
\hline & Natrium $(\mathrm{Na})$ & 5,83 \\
\hline & Klor $(\mathrm{Cl})$ & 2,46 \\
\hline & Perak (Ag) & 38,41 \\
\hline \multirow{5}{*}{8} & Karbon ( C ) & 27,24 \\
\hline & Oksigen $(\mathrm{O})$ & 24,58 \\
\hline & Natrium $(\mathrm{Na})$ & 4,14 \\
\hline & Klor $(\mathrm{Cl})$ & 3,05 \\
\hline & Perak (Ag) & 40.9 \\
\hline \multirow{5}{*}{9} & Karbon (C) & 11,56 \\
\hline & Oksigen $(\mathrm{O})$ & 9,63 \\
\hline & Natrium $(\mathrm{Na})$ & 2,92 \\
\hline & Klor $(\mathrm{Cl})$ & 5,05 \\
\hline & Perak (Ag) & 38,65 \\
\hline
\end{tabular}

Gambar 7. Komposisi Kimia Hasil Sintesis Nanopartikel Perak pH 6-9 

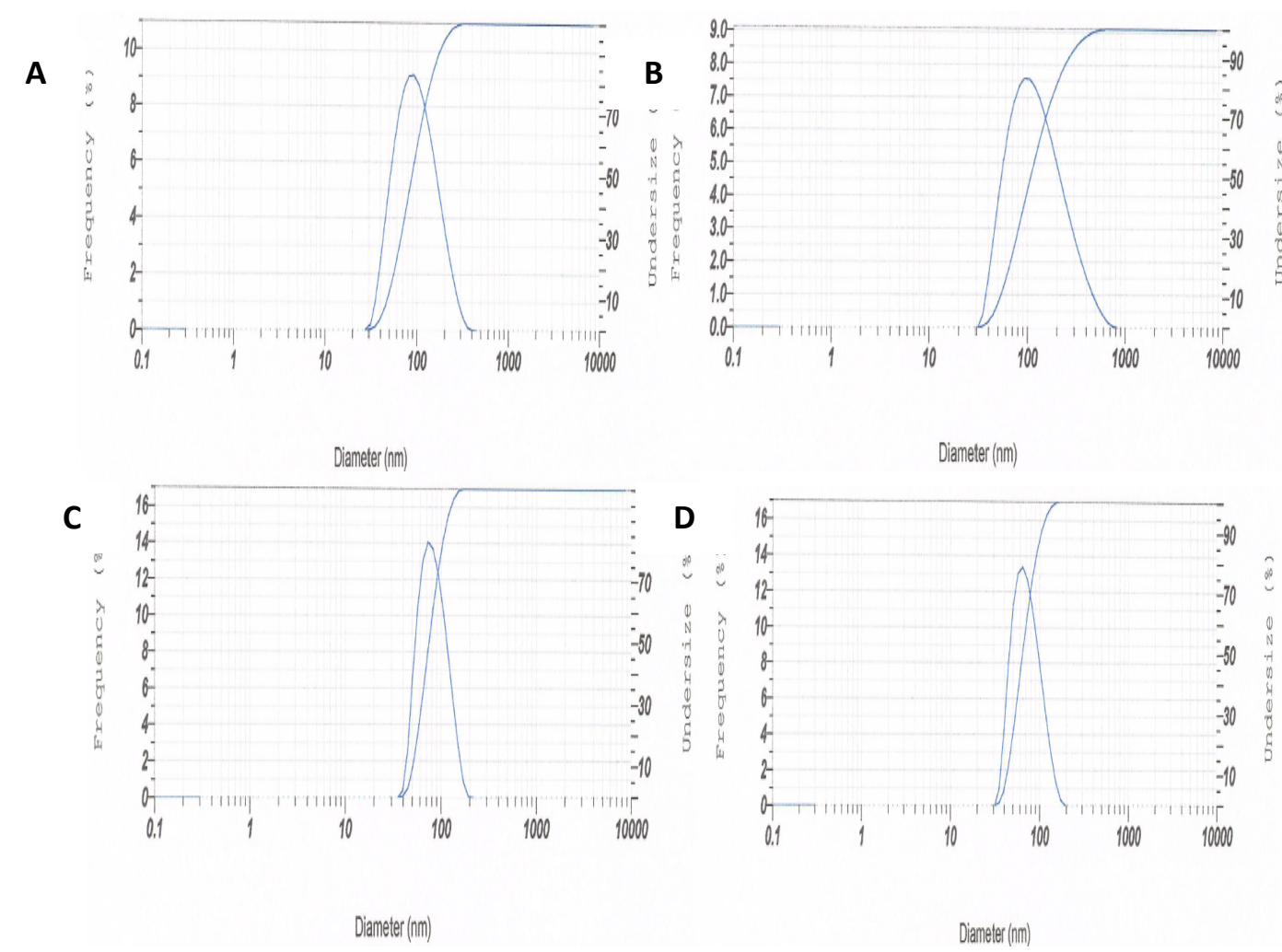

Gambar 8. Grafik Distribusi Ukuran Hasil Sintesis Nanopartikel Perak (A) $\mathrm{pH} 6$, (B) $\mathrm{pH} 7$, (C) $\mathrm{pH} 8$, dan (D) $\mathrm{pH} 9$

Ukuran atau $\begin{array}{r}\text { diameter } \\ \text { dapat diukur }\end{array}$
nanopartikel $\begin{array}{r}\text { dat } \\ \text { menggunakan }\end{array}$ PStrumen PSA.
Ukuran/diameter nanopartikel perak
hasil sintesis dapat dilihat pada
Gambar 8 .
Ukuran rata-rata nanopartikel
perak dari hasil perhitungan Z-
Average Instrument, untuk pH 6
sebesar $91 \mathrm{~nm}$ pH 7 sebesar 106,3
$\mathrm{~nm}$, pH $8 \mathrm{sebesar} 71,7 \mathrm{~nm}$, dan pH 9
sebesar $64,4 \mathrm{~nm}$. Ditinjau dari ukuran
partikel, keempatnya telah masuk
dalam skala nanopartikel, Dimana
ukuran 1-100 nm yaitu partikel ultra
halus, dan $100-2500 \mathrm{~nm}$ yaitu partikel
halus. Dan $1000 \mathrm{~nm}=1 \mu \mathrm{m}$ (Laroui,

dkk., 2011). Pada penelitian ini ukuran nanopartikel perak yang terkecil diperoleh pada $\mathrm{pH} 9$ yaitu, $64,4 \mathrm{~nm}$.

\section{KESIMPULAN DAN SARAN}

\section{A. Kesimpulan}

Berdasarkan penelitian yang telah dilakukan, maka dapat disimpulkan:

1. Waktu sintesis optimal dalam sintesis nanopartikel menggunakan bioreduktor ekstrak daun teh hijau dengan iradiasi microwave yaitu 4 menit. $\mathrm{pH}$ stabilizer tidak terlalu berpengaruh pada hasil morfologi 
namun berpengaruh pada ukuran distribusi nanopartikel perak.

2. Karakterisasi nanopartikel yang dihasilkan dari proses sintesis adalah morfologi permukaan nanopartikel perak untuk keempat sampel masih terdapat gumpalan(agregasi), dan ukuran nanopartikel perak terkecil diperoleh pada $\mathrm{pH} 9$ yaitu sebesar $64,4 \mathrm{~nm}$.

\section{B. Saran}

Berdasarkan hasil yang telah diperoleh dari penelitian ini, maka diperlukan penelitian lebih lanjut mengenai sintesis dengan variasi konsentrasi $\mathrm{AgNO}_{3}$ dengan iradiasi microwave, penggunaan stabilizer sintesis nanopartikel perak sehingga mendapatkan kestabilan yang baik, dan aplikasi pemanfaatan nanopartikel perak.

\section{DAFTAR PUSTAKA}

Arifin, Nurul., Harjono dan Nanik Wijayanti. 2016. Sintesis Nanopartikel Perak menggunakan Daun Jambu Biji (Psidium guajava L.) dengan Irradiasi Microwave. Indonesiam Journal of Chemical Science. Vol. 5, No. 3.

Kudle, K.R., M.R. Donda, R. Merugu, Y. Prashanti dan M.P. Pratap Rudra. 2013. Microwave Assisted Green Synthesis of Silver Nanoparticles using Stigmaphyllon littorale leaves, Their Characterization and AntiMicrobial Activity. International Journal of Nanomaterials and Biostructures, 3(1): 13-16
Krithiga, Narayanaswamy., Athimoolam Rajalakshmi dan Ayyavoo Jayachitra. 2015. Green Synthesis of Silver Nanoparticles Using Leaf Extracts of Clitoria ternatea and Solanum nigrum and Study of Its Antibacterial Effect against Common Nosocomial Pathogens. Journal of Nanoscience. Volume 2015, Article ID 928204, 8 pages.

Loo, Yuet Ying., Buong Woei Chieng, Mitsuaki Nishibuchi dan Son Radu. 2012. Synthesis of silver nanoparticles by using tea leaf extract from Camellia Sinensis. International Journal of Nanomedicine. Vol 7. Hal. 42634267.

Mallikarjuna, K., G. Narasimha, G. R. Dillip, B. Praveen, B. Shreedhar, C. Sree Lakshmi, B. V. S. Reddy dan B. Deva Prasad Raju. 2011. Green Synthesis of Silver Nanoparticles Using Ocimum Leaf Extract and Their Characterization. Digest Journal of Nanomaterials and Biostructures. Vol. 6, No. 1.

Naik, L. Srinivas., K. Paul Marx, P. Sree Vennela dan Venkata Ramana Devi. 2013. Green synthesis of silver nanoparticles using Strawberry leaf extract (Arbutus unedo) and evaluation of its antimicrobial activity-a Novel study. International Journal of Nanomaterials and Biostructures; Vol. 3, No. 3, Hal: 47-50

Negara, Satria Putra Jaya. 2017. Sintesis Nanopartikel Perak dengan Ekstrak Metanol Daun 
Teh Hijau. Skripsi. Makassar : Univesitasi Negeri Makassar.

Ponarulselvam, S., Panneerselvam C, Murugan K, Aarthi N, Kalimuthu K dan Thangamani S. 2012. Synthesis of silver nanoparticles using leaves of Catharanthus roseus Linn. G. Don and their antiplasmodial activities. Asian Pacific Journal of Tropical Biomedicine. Vol. 2, No. 7.

Punuri, J.B., P. Sharma, S. Sibyala, R. Tamuli dan U. Bora. 2012. Piper betle- Mediated Green Synthesis of Biocompatible Gold Nanoparticles International Nano Letters, 2(18): 1-9.
Purnamasari, Margareta Dian., Harjono dan Nanik Wijayanti. 2016. Sintesis Antibakteri Nanopartikel Perak menggunakan Bioreduktor Ekstrak Daun Sirih dengan Irradiasi Microwave. Skripsi. Semarang : Universitas Negeri Malang.

Mineral Dan Batubara, 8 (1).

Yasin, Sohail., Lin Liu dan Juming Yao. 2013. Biosynthesis of Silver Nanoparticles by Bamboo Leaves Extract and Their Antimicrobial Activity. Journal of Fiber Bioengineering and Informatics. Vol. 6, No. 1. 